\title{
Observasi Jenis-Jenis Burung Pada Kawasan Bernilai Konservasi Tinggi PT. Gunung Gajah Abadi
}

\author{
Chandradewana Boer ${ }^{1}$ dan Rustam ${ }^{2}$ \\ 1,2 Laboratorium Ekologi Satwaliar dan Biodiversity, \\ Fakultas Kehutanan, Universitas Mulawarman \\ ${ }^{1}$ Email: chandradewanaboer@gmail.com
}

\begin{abstract}
The research objective was to see the diversity of bird species within the PT GGA area which has been designated as an area with high conservation value. Less than 100 species was observed and identified by the combination of methodology i.e watching, voices, mist netting and camera trapping. Some species of bird are rare species, endangered, endemic one and vulnerable. All of the Nectarinidae, Bucerotidae, Accipitridae and Alcedinidae are protected by the law of Indonesian goverment. More insectivore was identified than the other trophic groups. Polypectron schleiermacheri (Endagered, IUCN, Appendix II, CITES), Lophura ignita and Carpococys radiceus were trapped by the camera and indicated how importance the forest within the area of PT. Gunung Gajah Abadi to be protected in any forest parts is.
\end{abstract}

Keywords: High Conservation Value Forest, Trophic Group, Voices of Bird Identification, Camera Trapping, Observation

\begin{abstract}
ABSTRAK
Tujuan penelitian untuk melihat keanekaragaman jenis burung didalam kawasan PT GGA yang telah ditetapkan sebagai areal dengan nilai konservasi tinggi. Kurang dari 100 jenis burung diamati dan diidentifikasi dengan kombinasi metode yaitu dengan cara pengamatan, mendengarkan suara, jala kabut dan perangkap kamera. Setiap burung yang terdeteksi diidentifikasi jenisnya dan dilihat kelas makan dan statusnya. Beberapa jenis burung adalah spesies yang jarang ditemukan, terancam punah, endemik dan rentan. Insektivora lebih banyak diidentifikasi daripada kelompok kelas makan lainnya. Polypectron schleiermacheri (Endagered, IUCN, Appendix II, CITES), Lophura ignita dan Carpococys radiceus terperangkap oleh kamera dan menunjukkan betapa pentingnya hutan di dalam area PT. Gunung Gajah Abadi untuk dilindungi.

Kata kunci: Kawasan Bernilai Konservasi Tinggi, Kelas Makan, Identifikasi Lewat Suara, Kamera Perangkap, Observasi
\end{abstract}

\section{Pendahuluan}

Observasi fauna pada satu daerah dapat memberikan petunjuk tentang rona awal yang dapat dijadikan acuan dalam melihat perubahan yang terjadi akibat satu atau lebih aktifitas pembangunan yang akan dilakukan. Saling ketergantungan antar banyak jenis, khususnya antara kelompok hewan dan tumbuhan sudah banyak diketahui, seperti penyedia makanan berupa buah dan bunga, sebagai penyerbuk tanaman berbunga, penyebar biji dan lain sebagainya (Allen, 1953; Leighton, 1983; Alikodra, 2002). Dengan ditebangnya beberapa pohon besar dari jenis Dipterocarpaceae di hutan alam primer seperti di PT. Gunung Gajah Abadi (PT. GGA) akan berdampak besar terhadap flora dan fauna di dalamnya. Daerah bekas tebangan pohon tersebut disebut dengan rumpang (Gaps) yang akan mempengaruhi regenerasi hutan secara signifikan dan terhadap 
komposisi jenis satwaliar yang jadi penghuninya, khususnya kelompok Avifauna atau burung (Thiollay, 1997; Boer, 1998; Boer, 2018). Selain itu masih harus dilihat kondisi secara umum daerah berhutan disekitar kawasan (tapak proyek), sehingga kehilangan jenis secara dramatis masih akan dapat diminimalisir dengan adanya tempat-tempat menyelamatkan diri (refuge area) bagi banyak jenis satwaliar dari aktifitas penebangan secara langsung (Lambert, 1992; Boer, 1993; Boer, 2006). Penelitian ini bertujuan untuk melihat keanekaragaman jenis burung didalam kawasan PT GGA yang telah ditetapkan sebagai areal dengan nilai konservasi tinggi untuk kepentingan pengelolaan kawasan secara keseluruhan.

\section{Metode Penelitian}

Observasi jenis-jenis burung dilaksanakan di lokasi penelitian yang merupakan areal yang dicadangkan sebagai areal Plasma Nutfah (KPPN), dan areal sekitar $12 \mathrm{~km}$ dari Camp utama yang merupakan daerah sepan (tempat mengasin satwaliar). Penelitian dilaksanakan efektif selama kurang lebih 5-8 hari pada tahun 2014. Menggunakan metode pengamatan langsung dengan menggunakan teropong (binocular) dan kamera sebagai alat bantu dokumentasi dan juga identifikasi, serta dibantu dengan beberapa buku panduan lapangan. Tujuan pengamatan adalah mendapatkan sebanyak mungkin jumlah jenis burung yang ada di dalam kawasan yang disurvey. Setiap kali melihat burung lalu diidentifikasi jenisnya saja tanpa memperhatikan jumlahnya karena tidak bertujuan melihat struktur komunitas burung di kawasan tersebut. Observasi dilakukan dengan cara mengikuti jalan yang sudah tersedia sebagai pengganti jalur/transek yang membelah kawasan dari utara ke selatan. Kegiatan pengamatan dilakukan pada daerah bervegetasi yang terlewati seperti dibawah tegakan hutan, semak belukar ataupun daerah tepi sungai, khususnya pada sekitar daerah pakan satwaliar (pohon buah) ataupun pada bekas-bekas satwaliar yang ditemukan, baik berupa jejak kaki, kotoran ataupun lainnya. Daerah tepi hutan juga merupakan tempat yang baik untuk pengamatan burung. Pengamatan secara efektif dilakukan pada pagi dan sore hari dimana satwa burung (aves) dan sebagian besar satwaliar lainnya sedang aktif melakukan pergerakan baik untuk mencari makan ataupun aktifitas bergerak lainnya. Tambahan dari pengamatan adalah pemasangan jala kabut (mist net) untuk menangkap burung. Jala dibiarkan terpasang selama 2-3 hari siang dan malam pada beberapa titik dengan 2 kali pindah lokasi pemasangan. Kontrol jala dilakukan setiap 2 jam dan setiap 1 jam bila hujan turun oleh 2 orang yang berbeda (asisten peneliti) (Boer, 1998). Untuk mendapatkan tambahan jenis yang bervariasi dilakukan juga identifikasi lewat suara dan pemasangan kamera perangkap (camera trapping) untuk mendapatkan jenis-jenis yang hidup di lantai hutan. Pemasangan kamera diutamakan untuk mendapatkan data mammalia yang dibiarkan terpasang sebanyak 10 
kamera selama 2 bulan. Untuk analisis burung-burung tersebut hanya dikelompokkan berdasarkan kelas makan (Wong, 1983; Boer, 1998) untuk mendapatkan gambaran tentang jaring-jaring makanan dan berapa banyak jenis didalam satu kelas makan tersebut.

\section{Hasil dan Pembahasan}

Berdasarkan sistem administrasi kehutanan, PT GGA termasuk ke dalam wilayah kelola Kesatuan Pengelolan Hutan Produksi (KPHP) Kelinjau, Kabupaten Kutai Timur, Provinsi Kalimantan Timur. Menurut posisi geografis, areal PT. GGA terletak antara garis lintang $116^{\circ} 40^{\prime}-117^{\circ} 02^{\prime}$ Bujur Timur dan $1^{\circ} 20^{\prime}-1^{\circ} 35^{\prime}$ Lintang Utara dengan ketinggian tempat 25-250 meter di atas permukaan laut. Sebelah Utara berbatasan dengan PT. Karya Lestari di Sebelah Selatan dengan Perkebunan Kelapa Sawit PT. Nusantara Agro, di sebelah Timur dengan PT. Utama Damai Indah Timber dan Eks PT. Kayu Kalimantan dan disebelah sebelah baratnya berbatasan dengan Eks PT. Loka Hutan Timur dan Narkata Rimba Timber. Pada konsesi PT. GGA telah ditetapkan beberapa kawasan sebagai apa yang disebut dengan HCVF (High Conservation Value Forest) atau NKT (Nilai Konservasi Tinggi) seperti area KPPN (Kawasan Pelestarian Plasma Nutfah) ataupun beberapa daerah tertentu (seperti sempadan sungai) yang menjadi tempat kebanyakan satwaliar untuk berlindung. Hasil identifikasi jenis burung yang terlihat, terdengar dan tertangkap selama penelitian di lapangan dapat dilihat pada Tabel 1.

Tabel 1. Jenis-jenis burung yang teridentifikasi (terlihat, terdengar dan tertangkap) selama penelitian di PT. GGA bersama kelas makannya

\begin{tabular}{llll}
\hline Jenis & Nama Indonesia & Nama Inggris & KM \\
\hline Aceros undulatus & Julang emas & Whreated hornbill & AF/P \\
Aegithina tiphia & Cipoh kacat & Common iora & NIF \\
Aethopyga siparaja & Burung-Madu Sepah-Raja & Crimson Sunbird & NIF \\
Alcedo athis & Raja Udang Erasia & Common Kingfisher & Insc/Pisc \\
Alcippe brunneicauda & Wergan coklat & Brown fulvetta & AFGIF \\
Alophoixus bres & Empuloh Janggut & Grey-cheeked Bulbul & AFGI/F \\
Alophoixus phaeocephalus & Empuloh irang & Yellow-bellied Bulbul & AFGI/F \\
Anorrhinus galeritus & Enggang klihingan & Bushy-crested hornbill & AF/P \\
Anthracoceros malayanus & Kangkareng hitam & Asian black hornbill & AF/P \\
Anthreptes simplex & Burung-Madu Polos & Plain Sunbird & NIF \\
Arachnothera affinis & Pijantung Gunung & Grey-breasted Spiderhunter & NI \\
Arachnothera longirostra & Piajantung Kecil & Little Spiderhunter & NI \\
Argusianus argus & Kuau Raja & Great Argus & TIF \\
Buceros rhinoceros & Rangkong badak & Rhinoceros hornbill & AF/P \\
Buceros vigil & Rangkong gading & Helmeted hornbill & AF/P \\
Cacomantis merulinus & Wiwik kelabu & Plaintive cuckoo & AFGI \\
Cacomantis sonneratii & Wiwik lurik & Banded bay cuckoo & AFGI \\
Carpoccyx radiceus & Tokhtor Sunda & Sunda Ground Cuckoo & TIF \\
Centopus bengalensis & Bubut Alang-alang & Lesser Cougal & AFGI \\
Centropus sinensis & Bubut Besar & Greater Coucal & TI \\
Ceyx erithacus & Udang api & Black-backed kingfisher & Insc/Pisc \\
Chalcopaps indica & Delimukan Zamrud & Emerald Dove & TIF \\
Chloropsis cochinchinensis & Cica-daun Sayap Biru & Blue-winged Leafbird & NIF \\
Chloropsis sonnerati & Cica daun besar & Greater green leafbird & NIF \\
Chrysocolaptes lucidus & Pelatuk tunggir emas & Greater Goldenback & BGI \\
\hline
\end{tabular}

Jpt. Jurnal Pertanian Terpadu, Jilid 8, Nomor 2 | 156 
ISSN 2354-7251 (print)

\begin{tabular}{|c|c|c|c|}
\hline Collocalia esculenta & Walet sapi & Glossy swiftlet & $\mathrm{Al}$ \\
\hline Collocalia fuciphaga & Walet sarang-putih & Edible-nest swiftlet & $\mathrm{Al}$ \\
\hline Copsychus malabaricus & Kucica hutan & White rumped shama & AFGI \\
\hline Copsychus saularis & Kucica kampung & Magpie robin & AFGI \\
\hline Corvus enca & Gagak hutan & Slender-billed crow & $\mathrm{AFGI} / \mathrm{F}$ \\
\hline Cuculus micropterus & Kangkok india & Indian cuckoo & AFGI \\
\hline Cuculus saturatus & Kangkok ranting & Oriental cuckoo & AFGI \\
\hline Dicrurus aeneus & Srigunting Keladi & $\begin{array}{l}\text { Bronzed Drongo } \\
\text { Greater Racket-tailed }\end{array}$ & SSGI \\
\hline Dicrurus paradiseus & Srigunting Batu & Drongo & SSGI \\
\hline Dryocopus javensis & Pelatuk Ayam & White-bellied Woodpecker & BGI \\
\hline Ducula aenea & Pergam Hijau & Green imperial pigeon & $\mathrm{AF}$ \\
\hline Ducula badia & Pergam gunung & Mountain imperial pigeon & $\mathrm{AF}$ \\
\hline Eurylaimus javanicus & Sempur hujan rimba & Banded broadbill & SSGI \\
\hline Eurylaimus ochromalus & Sempur hujan darat & Black and yellow broadbill & SSGI \\
\hline Eurystomus orientalis & Tiong Lampu & Dollarbird & $\mathrm{AF}$ \\
\hline Ficedula dumetoria & Sikatan Dada Merah & Rufous chested Flycatcher & $\mathrm{Al}$ \\
\hline Gracula religiosa & Tiong emas & Hill myna & $\mathrm{AF}$ \\
\hline Haliastur indus & Elang Bondol & Brahminy kite & $\mathrm{R}$ \\
\hline Harpactes kasumba & Luntur kasumba & Red naped trogon & SSGI \\
\hline Harpactes orrhophaeus & Luntur Tunggir Coklat & Cinnamon-rumped Trogon & SSGI \\
\hline Hemiprocne comata & Tepekong rangkang & Whiskered treeswift & SI \\
\hline Hirundo rustica & Layang-layang Api & Barn Swallow & $\mathrm{SI}$ \\
\hline $\begin{array}{l}\text { Hirundo tahitica } \\
\text { Hypogramma }\end{array}$ & Layang-layang Batu & Pasific Swallow & $\mathrm{SI}$ \\
\hline hypogrammicum & Burung madu rimba & Purple-naped Sunbird & NIF \\
\hline Ictinaetus malayensis & Elang Hitam & Black Eagle & $\mathrm{R}$ \\
\hline Irena puella & Kacembang Gadung & Asian Fairy-Bluebird & $\mathrm{AF}$ \\
\hline Lonchura fuscans & Bondol kalimantan & Dusky munia & TF \\
\hline Lonchura leucogastra & Bondol Perut Putih & White bellied Munia & TF \\
\hline Lonchura malacca & Bondol rawa & Black headed munia & TF \\
\hline Lophura ignita & Sempidan Biru Kalimantan & Crested Fireback & TIF \\
\hline Loriculus galgulus & Serindit melayu & Blue crowned hanging parrot & NF \\
\hline Macronous gularis & Ciung Air Koreng & Striped tit -babbler & AFGI \\
\hline Macronous ptilosus & Ciung air pongpong & Fluffy backed tit babbler & AFGI \\
\hline Malacopteron cinereum & Asi topi sisik & Scaly crowned babbler & AFGI \\
\hline Malacopteron magnirostre & Asi kumis & Moustached babbler & AFGI \\
\hline Megalaima australis & Takur tenggeret & Blue-eared barbet & $\mathrm{AF}$ \\
\hline Megalaima henricii & Takur topi-emas & Yellow-crowned barbet & AF \\
\hline Meiglyptes tukki & Caladi Badok & Buff-necked Woodpecker & BGI \\
\hline Microhierax fringillarius & Alap-alap capung & Black thighed falconet & $\mathrm{R}$ \\
\hline Muscicapa dauurica & Sikatan bubik & Asian brown flycatcher & SI \\
\hline Oriolus xanthonotus & Kepudang Hutan & Dark-throated Oriole & AFGI/F \\
\hline Orthotomus atrogularis & Cinenen belukar & Dark necked tailorbird & AFGI \\
\hline Orthotomus cuculatus & Cinenen gunung & Mountain tailorbird & AFGI \\
\hline Orthotomus ruficeps & Cinenen kelabu & Ashy tailorbird & AFGI \\
\hline Orthotomus sericeus & Cinenen merah & Rufous-tailed Tailorbird & AFGI \\
\hline Pericrocotus igneus & Sepah tulin & Fiery minivet & AFGI \\
\hline Phaenicopheaus diardi & Kadalan beruang & Black-bellied malkoha & AFGI \\
\hline Philentoma pryhopterum & Philentoma Sayap Merah & Rufous Winged Philentoma & $\mathrm{SI}$ \\
\hline Picus miniaceus & Pelatuk Merah & Banded Woodpecker & BGI \\
\hline Pitta granatina & Paok delima & Garnet pitta & $\mathrm{TI}$ \\
\hline $\begin{array}{l}\text { Pitta moluccensis } \\
\text { Polyplectron }\end{array}$ & Paok hujan & Blue winged pitta & $\mathrm{TI}$ \\
\hline schleiermacheri & Kuau kerdil kalimantan & $\begin{array}{l}\text { Bornean Peacock-pheasant } \\
\text { Yellow breasted }\end{array}$ & TIF \\
\hline Prionochilus maculatus & Pentis Raja & flowerpecker & $\mathrm{AFGI} / \mathrm{F}$ \\
\hline Ptilinopus jambu & Walik jambu & Jambu fruit-dove & TF \\
\hline Pycnonotus atriceps & Cucak Kuricang & Black-headed Bulbul & AFGI/F \\
\hline Pycnonotus aurigaster & Cucak Kutilang & Sooty-headed Bulbul & AFGI/F \\
\hline Pycnonotus brunneus & Merbah Mata-Merah & Red-eyed Bulbul & $\mathrm{AFGI} / \mathrm{F}$ \\
\hline Pycnonotus goiavier & Merbah Cerukcuk & Yellow-vented Bulbul & AFGI/F \\
\hline
\end{tabular}




\begin{tabular}{|c|c|c|c|}
\hline Pycnonotus simplex & Merbah Corok-corok & Cream-vented Bulbul & $\mathrm{AFGI} / \mathrm{F}$ \\
\hline Rhipidura javanica & Kipasan Belang & Pied Fantail & SI \\
\hline Rhipidura perlata & Kipasan Mutiara & Spotted Fantail & SI \\
\hline Sasia abnormis & Tukik Tikus & Rufous Piculet & AFGI \\
\hline Sitta frontalis & Munguk beledu & Velvet fronted nuthatch & BGI \\
\hline Spilornis cheela & Elang ular bido & Crested serpent eagle & $\mathrm{R}$ \\
\hline Stachyris erythroptera & Tepus merbah sampah & Chestnut winged babbler & AFGI \\
\hline Stachyris poliocephala & Tepus kepala kelabu & Grey headed babbler & AFGI \\
\hline $\begin{array}{l}\text { Streptopelia chinensis } \\
\text { Tephrodornis }\end{array}$ & Tekukur biasa & Spotted-dove & TF \\
\hline gularis/virgatus & Jingjing Petulak & Large woodshrike & AFGI \\
\hline Tersiphone paradisi & Seriwang Asia & $\begin{array}{l}\text { Asian Paradise-flycatcher } \\
\text { Cinnamon-headed green- }\end{array}$ & SI \\
\hline Treron fulvicollis & Punai bakau & pigeon & $\mathrm{AF}$ \\
\hline Tricasthoma abboti & Pelanduk Merah & Abbott's babbler & AFGI \\
\hline Tricasthoma malaccense & Pelanduk Ekor Pendek & Short tailed Babbler & AFGI \\
\hline Yuhina everreti & Yuhina Kalimantan & Chesnut-crested Yuhina & AFGI \\
\hline
\end{tabular}
Keterangan:

KM : Kelas Makan

AFGI (Arboreal foliage gleaning insectivore) : Jenis pemakan serangga yang mencari makan pada dedaunan AFGI/F (Arboreal foliage gleaning insectivore/frugivore): Jenis pemakan serangga yang mencari makan pada dedaunan dan juga makan buah

$\mathrm{TI}$ (Terrestrial insectivore) : Jenis pemakan serangga yang hidup di lantai hutan

$\mathrm{TI} / \mathrm{F}$ (Terrestrial insectivore/frugivore) : Jenis pemakan serangga dan buah yang hidup di lantai hutan

TF (Terrestrial frugivore) : Jenis pemakan buah yang hidup di lantai hutan

Al (Aerial insectivore) : Jenis pemakan serangga yang mencari makan di udara

AF (Arboreal frugivore) : Jenis pemakan buah yang hidup pada tajuk pohon

AF/P (Arboreal frugivore/predator) : Jenis pemakan buah yang hidup pada tajuk pohon dan seringkali jadi predator bagi binatang-binatang kecil

$\mathrm{NI}$ (Necativore/frugivore) : Jenis pemakan madu dan serangga

NIF (Nectarivore/insectivore/frugivore): Jenis pemakan madu, serangga dan buah

NF (Nectarivore/frugivore) : Jenis pemakan madu dan buah

I/P (insectivore/Piscivore) : Jenis pemakan serangga dan ikan

SI (Sallying insectivore) : Jenis pemakan serangga yang menangkap serangga di udara setelah menunggunya beberapa lama

SSGI (Sallying substrate gleaning insectivore): Jenis pemakan serangga yang menangkap mangsanya pada saat mereka hinggap pada dedaunan, setelah menunggunya beberapa lama

BGI (Bark gleaning insectivore): Jenis pemakan serangga yang mencari makan di balik-balik kulit kayu

Raptor : Jenis burung pemangsa, seperti dari famili Accipitridae yang memburu binatang-binatang kecil

Ditemukan sebanyak kurang dari 100 jenis burung (98 jenis) melalui metode pangamatan langsung (binocular), identifikasi lewat suara dan penangkapan ataupun secara tidak langsung melalui hasil dari pemasangan kamera trapping. Sebagian besar jenis yang teridentifikasi adalah pemakan serangga (insektivore) yang merupakan komposisi banyak jenis daerah terbuka dan jenis hutan alam (understorey), seperti Kacer (Copsychus saularis) adalah salah satu jenis komersil yang terdengar masih cukup banyak dan sering disekitar lokasi penelitian.

Kawasan PT. GGA adalah kawasan hutan tropis dataran rendah yang memang memiliki keragaman jenis yang tinggi baik flora maupun faunanya. Tingginya keragaman jenis flora biasanya diikuti oleh keragaman jenis yang tinggi juga dari faunanya, termasuk mamalia, burung dan serangga ataupun lainnya. Pada beberapa penelitian tentang komposisi jenis burung di Kalimantan Timur, banyak jenis (70\%) hanya diwakili oleh satu individu saja selama periode penelitian (Boer, 1994; Boer, 1998; Boer, 2004; Boer, 2006). 
Beberapa jenis burung yang ditemukan adalah termasuk kategori langka (terancam punah) dan dilindungi seperti semua jenis dari Family Bucerotidae (Enggang, Rangkong, Hornbills), sebagian besar jenis dari burung sesap madu (Family Nectarinidae), sebagian Raja Udang (Family Alcedinidae) dan semua jenis burung pemangsa (Accipitridae \& Falconidae).

Jenis endemik adalah Dusky munia Lonchura fuscans, yaitu sejenis burung Bondol yang hidup berkelompok. Namun demikian jenis burung ini belum berstatus langka, karena masih dapat ditemukan di hampir seluruh areal bervegetasi di banyak tempat di Kalimantan. Bersamaan dengan itu tercatat juga jenis Lonchura malacca jenis burung Bondol yang sering ditemukan (common species) dan memiliki penyebaran yang luas di pulau Kalimantan. Jenis endemik lainnya adalah Yuhina everreti yang teridentifikasi melalui suaranya yang dari penyebarannya adalah pada ketinggian di atas 200-1.800 m dpl (MacKinnon, 2010). Lainnya adalah juga yang sangat jarang ditemukan seperti Lophura ignita dan Polyplectron schleiermacheri. Berikut adalah gambar Kuau Kerdil Kalimantan, jenis yang jarang ditemukan yang terekam pada kamera trapping.

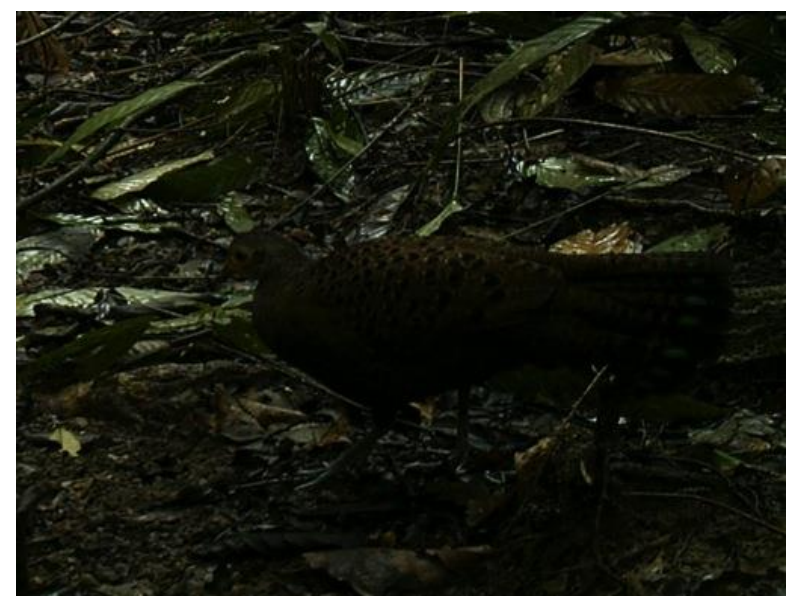

Gambar 1. Kuau Kerdil Kalimantan yang tertangkap pada camera trapping

\section{Kelas Makan dan Ketersediaan Makanan}

Kelas makan adalah salah satu cara pengelompokan yang lain dari banyaknya jenis-jenis burung di hutan tropis (Boer, 1998; Wong, 1983). Kelas makan umumnya melihat kepada jenis makanan secara umum dari burung-burung tersebut, kemudian dipelajari juga tentang bagaimana dan dimana makanan tersebut diperoleh dan terakhir diperlukan juga informasi tentang bagaimana perilaku jenis untuk mendapatkan makanan tersebut. Misalnya burung-burung yang mencari makanan diantara dedaunan pada bagian tajuk pohon dikategorikan sebagai arboreal foliage gleaning insectivore. Aerial insectivore adalah jenis-jenis yang memburu mangsanya berupa serangga di udara atau terrestrial frugivore adalah burung-burung pemakan buah yang hidup di lantai hutan dan 
sebagainya. Tabel berikut memperlihatkan daftar jenis burung dan kelas makannya di lokasi PT. GGA, Kabupaten Kutai Timur, Kalimantan Timur

Tabel 2. Kelompok makan dan penyebaran jumlah jenis burung yang ditemukan di PT. GGA, Kabupaten Kutai Timur, Kalimantan Timur

\begin{tabular}{lllc}
\hline \multicolumn{1}{c}{ Kelompok } & \multicolumn{1}{c}{ Kelas Makan } & Feeding guild & Jumlah jenis \\
\hline Specialist & Frugivore & Terrestrial & 5 \\
& & Arboreal & 8 \\
\cline { 2 - 4 } & Insectivore & Terrestrial & 3 \\
& & Arboreal & 24 \\
& & Bark gleaning & 5 \\
& & Sallying & 14 \\
& & Aerial & 3 \\
\hline Generalist & Insect-Frugivore & Terrestrial & 5 \\
& & Arboreal & 11 \\
\cline { 2 - 4 } & Frugivore/Predator & Arboreal & 5 \\
\cline { 2 - 4 } & Insec/Piscivore & & 2 \\
\cline { 2 - 4 } & Insec/Nectarivore & & 2 \\
\cline { 2 - 4 } & Nectarivore/Frugivore & & 4 \\
\cline { 2 - 4 } & Ins/Nectar/Frugivore & & 4 \\
\hline Carnivore & Predator/Noc & Raptor & \\
\hline
\end{tabular}

Secara umum lebih banyak ditemukan jenis-jenis yang hidup arboreal dibandingkan dengan kelompok terrestrial untuk kelompok pemakan hanya buah-buahan (specialist) (8 jenis vs 5 jenis). Begitu juga pada pemangsa serangga jenis arboreal lebih banyak ditemukan dibandingkan yang terrestrial, namun demikian pemakan serangga yang mencari mangsanya dengan cara menungguinya (Sallying) dibalik dedaunan diperkirakan lebih banyak dibanding dengan yang memburu mangsa secara langsung diudara (aerial).

Kecenderungan yang sama terlihat pada kelompok generalist dimana ditemukan banyak jenis pada daerah tajuk pohon (arboreal) dibandingkan dengan daerah terrestrial. Begitu juga untuk kelompok makan lainnya seperti jenis raptor atau pemakan daging, pemakan ikan dan atau pemakan serangga dan madu bunga, memperlihatkan jumlah jenis yang tidak cukup banyak. Jumlah jenis burung pemakan serangga umumnya ditemukan lebih banyak dibandingkan pemakan buah (Boer, 1998) dan jenis-jenis yang tergabung dalam kelompok specialist ditemukan lebih banyak dibandingkan yang generalist. Hal ini memberi petunjuk bahwa banyak jenis burung di kawasan PT. GGA adalah lebih rentan terhadap ketersediaan pakan, mengingat specialist diartikan sebagai memerlukan makanan yang spesifik, seperti serangga tertentu ataupun buah tertentu sebagai makanan.

Keberadaan jenis burung di satu lokasi dapat menjadi petunjuk yang baik tentang kondisi di lokasi tersebut, terutama yang berhubungan dengan pakan yang dapat berupa vegetasi ataupun serangga dan ataupun jenis pakan lainnya (misalnya cacing tanah ataupun banyak jenis lainnya) (Boer, 2006). Berikut adalah beberapa gambar hasil penangkapan burung selama di lokasi penelitian. 

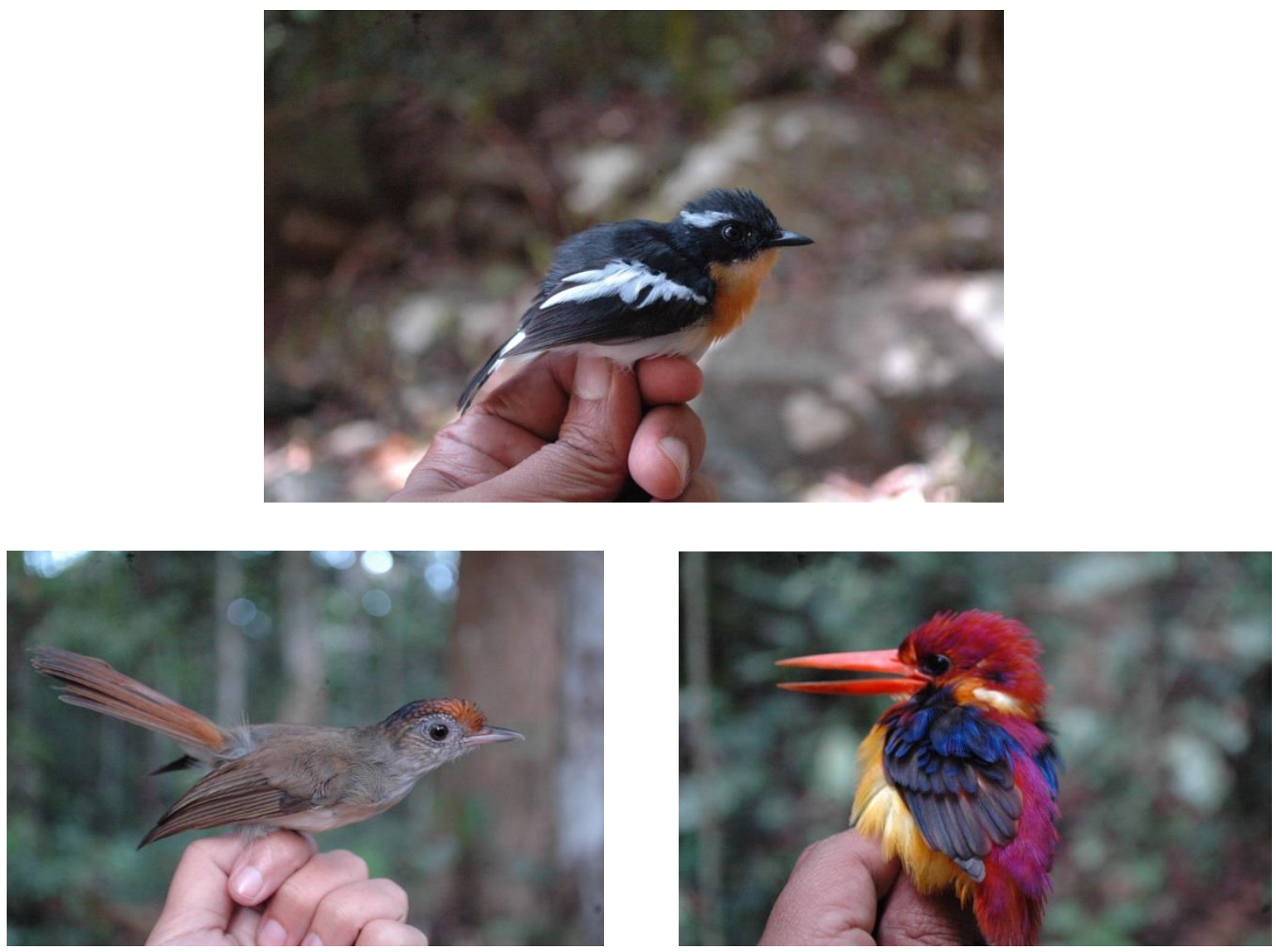

Gambar 2. Ficedula dumetoria (Aerial Insectivore, Al) (atas), Malacopteron cinereum (Arboreal foliage gleaning Insectivore, AFGI) (kiri bawah) dan Ceyx erythacus (Insectivore/Piscivore) (kanan bawah).

Selain itu ditampilkan juga jenis burung Tiong yang dikenal sebagai pemakan buah pada gambar berikut ini:
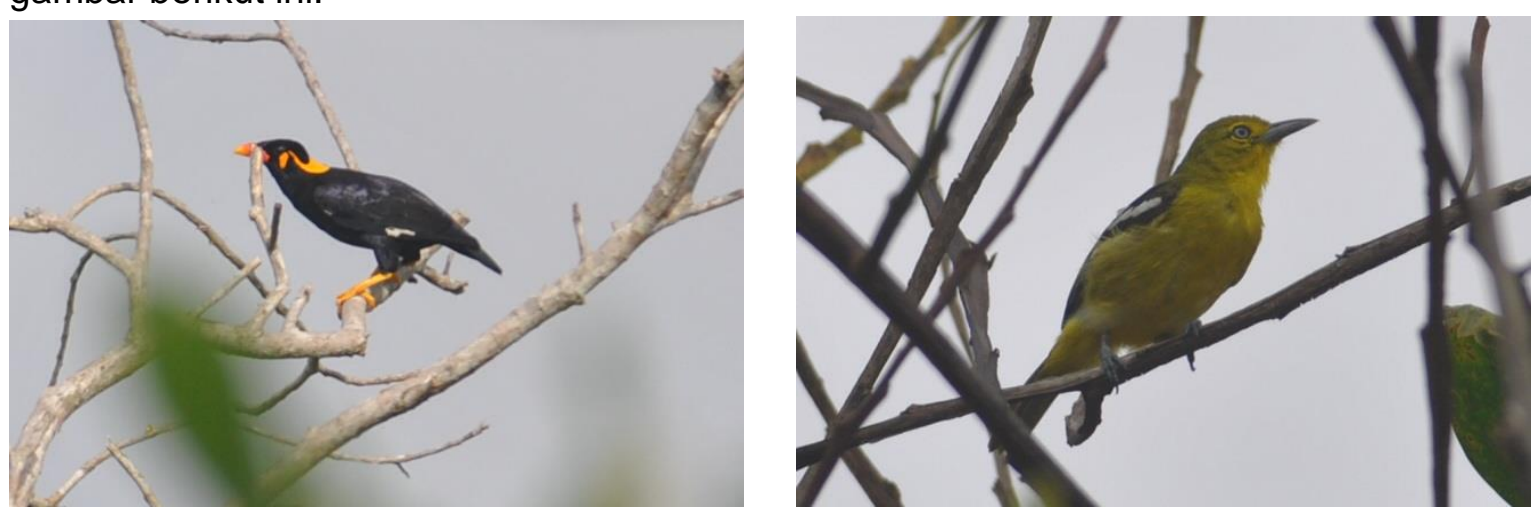

Gambar 3. Tiong, Gracula religiosa (Aerial Frugivore) (kiri) dan Cipoh Kacat, Aegithina tiphia (Nectarivore/Insectivore/Frugivore, NIF) (kanan). 


\section{Kesimpulan}

Jumlah jenis burung didalam kawasan PT. GGA cukup banyak. Hal ini dibuktikan dengan teridentifikasinya sebanyak 98 jenis burung melalui kombinasi metode pengamatan, identifikasi lewat suara, penangkapan dan hasil dari camera trapping. Diperkirakan jumlah jenis masih akan terus bertambah jika hari pengamatan ditambah dan sampel lokasi dipindahkan ke tempat lainnya, yaitu semakin menyebar ke dalam hutan yang belum terganggu. Jenis-jenis burung yang ditemukan termasuk ke dalam jenis hutan alam primer dataran rendah yang sebagian besarnya adalah memiliki populasi yang rendah dan oleh karena itu sangat rentan terhadap ancaman kepunahan. Beberapa jenis bahkan tercatat sebagai jenis yang rentan, langka (rare) ataupun endangered berdasarkan Red Data Book IUCN dan peraturan perundangan yang ada di Indonesia. Beberapa jenis dinyatakan pula sebagai jenis yang endemik Kalimantan yang merupakan nilai tambah konservasi yang positif namun rentan bagi kawasan tersebut.

\section{Daftar Pustaka}

Alikodra, H. S. (2002). Pengelolaan Satwaliar. Bogor: Yayasan Penerbit Fakultas Kehutanan IPB.

Allen, A. A. (1953). The book of bird life. Canada: Van Nostrand Company.

Boer, C. (1993). Bird species alpha-diversity a long a management gradient in the rain forests of East Kalimantan. Diplomarbeit. Wuerzburg University.

Boer, C. (1994). Comparative study of bird's species diversity in reference to the effect of logging operation, in Kalimantan Tropical Rain Forest. Proceeding of the International Symposium on Asian Tropical Forest Management, PUSREHUTUNMUL and JICA

Boer, C. (1998). Zur Bedeutung von Baumsturzlücken für die Verteilung und Abundanz von Vogelarten des Unterholzes in Primär- und Sekundärregenwäldern Ostkalimantan. Universität Würzburg. Dissertation

Boer, C. (2004). The significant role of wild animal diversity to succeed the forest restoration. BIO-REFOR. Seoul Korea.

Boer, C, (2006). The avian diversity in tropical forest dynamic. Natural Life, 1(1). 32-46.

Boer, C. (2010). Studi Tentang Keanekaragaman Jenis di Hutan Pendidikan Unmul Taman Hutan Raya Bukit Soeharto. Pusat Penelitian Hutan Tropis, Univ. Mulawarman

Boer, C. (2018). Observasi Keragaman Jenis Burung Pada Beberapa Daerah Hutan Yang Tersisa (HCVF) di dalam Perkebunan PT. Kalimantan Sakti Abadi, Kabupaten Kotawaringin Barat, Kalimantan Tengah. ULIN: Jurnal Hutan Tropis, 2(2), 70-78. https://doi.org/10.32522/u-jht.v2i2.1638 
Lambert, F. R. (1992). The consequences of selective logging for Bornean lowland forest birds. Philosophical Transactions of the Royal Society of London. Series B: Biological Sciences, 335(1275), 443-457.

Leighton, M. \& Leighton, D. R. (1983). Vertebrate Responses to Fruiting Seasonally within a Bornean Rain Forest in Tropical Rain Forest: Ecology and Management. Blackwell Scientific Publications, Oxford

MacKinnon, J. \& Philips, K. (2010). A Field Guide to the Birds of Borneo, Sumatra, Java and Bali. Oxford University Press

Thiollay, J. M. (1997). Disturbance, selective logging and bird diversity: a Neotropical forest study. Biodiversity and conservation, 6(8), 1155-1173.

Wong, M. (1983). Understory phenology of the virgin and regenerating habitats in Pasoh forest reserve, Negeri Sembilan, West Malaysia. The Malayan Forester, 46(2). 